Research article

Open Access

\title{
Analysis of bacterial DNA in synovial tissue of Tunisian patients with reactive and undifferentiated arthritis by broad-range PCR, cloning and sequencing
}

\author{
Mariam Siala ${ }^{1}$, Benoit Jaulhac ${ }^{2}$, Radhouane Gdoura ${ }^{1}$, Jean Sibilia², Hela Fourati ${ }^{3}$, \\ Mohamed Younes ${ }^{4}$, Sofien Baklouti ${ }^{3}$, Naceur Bargaoui ${ }^{4}$, Slaheddine Sellami ${ }^{5}$, Abir Znazen ${ }^{1}$, \\ Cathy Barthel ${ }^{2}$, Elody Collin², Adnane Hammami ${ }^{1}$ and Abdelghani Sghir6,7
}

\author{
1'Laboratoire de Recherche 'Micro-organismes et Pathologie Humaine', EPS Habib Bourguiba, Rue El Ferdaous, 3029 Sfax, Tunisie \\ 2Laboratoire de Physiopathologie des Interactions Hôte-bactérie, UPRES-EA 3432, Faculté de Médecine, Université Louis-Pasteur, rue Koeberlé, \\ 67000 Strasbourg, France \\ ${ }^{3}$ Service de Rhumatologie Hôpital Hedi Chaker, Avenue Majida Boulila, 3029 Sfax, Tunisie \\ ${ }^{4}$ Service de Rhumatologie, EPS Fattouma Bourguiba, Rue 1er Juin, 5019 Monastir, Tunisie \\ ${ }^{5}$ Service de Rhumatologie, EPS La Rabta, rue 7051 Centre Urbain Nord, 1082 Tunis, Tunisie \\ ${ }^{6}$ CNRS-UMR 8030, CEA-Genoscope, rue Gaston Crémieux, 91000 Évry, France \\ 7University of Evry Val d'Essonne, Boulevard François Mitterrand, 91025 Évry Cedex, 91000 Évry, France \\ Corresponding author: Adnane Hammami, adnene.hammami@rns.tn
}

Received: 27 Dec 2007 Revisions requested: 6 Feb 2008 Revisions received: 18 Mar 2008 Accepted: 14 Apr 2008 Published: 14 Apr 2008

Arthritis Research \& Therapy 2008, 10:R40 (doi:10.1186/ar2398)

This article is online at: http://arthritis-research.com/content/10/2/R40

(c) 2008 Siala et al.; licensee BioMed Central Ltd.

This is an open access article distributed under the terms of the Creative Commons Attribution License (http://creativecommons.org/licenses/by/2.0), which permits unrestricted use, distribution, and reproduction in any medium, provided the original work is properly cited.

\begin{abstract}
Introduction Bacteria and/or their antigens have been implicated in the pathogenesis of reactive arthritis $(\operatorname{Re} A)$. Several studies have reported the presence of bacterial antigens and nucleic acids of bacteria other than those specified by diagnostic criteria for $\operatorname{ReA}$ in joint specimens from patients with $\operatorname{ReA}$ and various arthritides. The present study was conducted to detect any bacterial DNA and identify bacterial species that are present in the synovial tissue of Tunisian patients with reactive arthritis and undifferentiated arthritis (UA) using PCR, cloning and sequencing.

Methods We examined synovial tissue samples from 28 patients: six patients with ReA and nine with UA, and a control group consisting of seven patients with rheumatoid arthritis and six with osteoarthritis (OA). Using broad-range bacterial PCR producing a 1,400-base-pair fragment from the 16S rRNA gene, at least 24 clones were sequenced for each synovial tissue sample. To identify the corresponding bacteria, DNA sequences were compared with sequences from the EMBL (European Molecular Biology Laboratory) database.
\end{abstract}

Results Bacterial DNA was detected in $75 \%$ of the 28 synovial tissue samples. DNA from 68 various bacterial species were found in ReA and UA samples, whereas DNA from 12 bacteria were detected in control group samples. Most of the bacterial DNAs detected were from skin or intestinal bacteria. DNA from bacteria known to trigger ReA, such as Shigella flexneri and Shigella sonnei, were detected in $\operatorname{ReA}$ and UA samples of synovial tissue and not in control samples. DNA from various bacterial species detected in this study have not previously been found in synovial samples.

Conclusion This study is the first to use broad-range PCR targeting the full 16S rRNA gene for detection of bacterial DNA in synovial tissue. We detected DNA from a wide spectrum of bacterial species, including those known to be involved in $\operatorname{ReA}$ and others not previously associated with $\operatorname{ReA}$ or related arthritis. The pathogenic significance of some of these intrasynovial bacterial DNAs remains unclear.

\section{Introduction}

Bacteria are considered to be important in the pathogenesis of several forms of arthritis, including reactive arthritis (ReA)
[1] or various other forms of post-infectious arthritis [2]. ReA is defined as an inflammatory arthritis, occurring approximately 4 weeks after an infection, with no cultivable bacteria detecta- 
ble in the joints [3,4]. Usually, the initial arthritogenic bacterial infection affects the urogenital tract (for example, Chlamydia trachomatis) or the digestive tract (Yersinia, Salmonella or Shigella spp., or Campylobacter jejeuni) [4]. ReA can also follow respiratory tract infections with Chlamydophila pneumoniae [5].

Many cases of ReA are preceded by infections that are asymptomatic [6]; such cases are clinically classified as undifferentiated arthritis (UA) $[7,8]$. This term describes patients who exhibit arthritis clinically similar to ReA, with high rates of monoarthritis or oligoarthrithis, and predominance of synovitis in the lower limbs. This has led several investigators to suggest a potential link between these two forms of arthritis, and that $U A$ and $\operatorname{ReA}$ are overlapping entities. Several groups have detected $C$. trachomatis DNA in the synovium of patients with UA [9], suggesting that some of these patients may have a 'forme fruste' of ReA.

Arthritogenic bacterial DNA and RNA from Chlamydia trachomatis, Chlamydophila pneumoniae, and Yersinia pseudotuberculosis have been detected by PCR in synovial samples from patients with ReA and UA. Thus, micro-organisms, or components thereof, do reach the joint but are not always cultivable [2,9-12]. This suggests that inflammation at the joint is caused by an immune response to bacterial antigens $[9,13]$. Bacterial DNA has also been detected in synovial samples from patients with other forms of arthritis, such as rheumatoid arthritis (RA) or osteoarthritis (OA) [14-16]. Detection of nucleic acids from other bacteria (Pseudomonas sp., Bacillus cereus, Mycobacterium tuberculosis, or Borrelia burgdorferi) in synovial fluid or synovial tissue (ST) from patients with ReA or other forms of arthritis (UA, RA, or OA) has raised the question of whether non-Chlamydia or nonenteric bacteria may enter the synovium and cause or contribute toward synovitis $[14,17-19]$. However, the list of pathogens that trigger ReA is not definitively established.

Several studies have addressed this issue, using broad-range PCR and/or reverse transcription PCR systems to search for bacterial DNA and RNA in synovial samples from patients with various forms of arthritis, including $\operatorname{ReA}[12,14,17]$. By cloning and sequencing the PCR products, they have shown that more than one micro-organism can be present in the same joint. In most studies, the PCR products were of sufficient length to determine the genus of the bacteria in the synovial samples, but were not long enough to identify the species level $[12,17]$.

In this study we aimed to identify bacterial DNA in patients with ReA and UA using broad-range PCR, cloning and sequencing of almost the entire 16S rRNA gene. The use of this approach revealed the identity of potential bacterial causes and the presence of previously uncharacterized and uncultured bacterial pathogens in joint disease. Despite the frequent occurrence of genital and intestinal infections in Tunisia [20-24], no studies of ReA-related bacteria have yet been conducted in this country.

\section{Materials and methods \\ Patients}

Twenty-eight patients with knee effusion, who had given informed consent, were included in the study after approval from our institutional review board. All patients were attending one of three rheumatology hospital departments in Tunisia. ST samples were obtained by needle biopsy from six patients with $\operatorname{ReA}$ (six posturethritic) and nine with $\mathrm{UA}$, and from a control group of seven patients with RA and six with OA. The patients' clinical features and demographic characteristics are summarized in Table 1.

ReA was diagnosed according to European Spondyloarthropathy Study Group and Amor criteria [25,26]. All of the cases of $\operatorname{ReA}$ were acquired sexually, with arthritis occurring within 4 weeks of an urogenital infection (Table 1). UA was defined as a monoarthritis or oligoarthritis occurring without evidence of a predisposing infection in a patient in whom other known rheumatic diseases had been excluded.

ST samples were taken from the knee joint using the ParkerPearson biopsy procedure [27]. Care was taken during and after obtaining patient samples to prevent cutaneous bacterial contamination. The skin surface was prepared with three successive betadine solution swabs, each for 2 minutes, and then with $70 \%$ alcohol for 2 minutes, before sampling. ST samples were immediately placed in sterile microcentrifuge tubes, which were closed and snap frozen in liquid nitrogen. Tubes were stored at $-80^{\circ} \mathrm{C}$ until analysis.

\section{Automated DNA extraction}

A DNA extraction procedure using the MagNA Pure system (Roche Molecular Biochemicals, Meylan, France) was used for all ST samples, using a pre-extraction treatment. Before MagNA Pure extraction, $500 \mu$ l lysis buffer $(200 \mathrm{mmol} / \mathrm{l} \mathrm{NaCl}$, $20 \mathrm{mmol} / / \mathrm{Tris} \mathrm{HCl}$ [pH 8], $50 \mathrm{mmol} / \mathrm{l} \mathrm{EDTA}$, and 1\% SDS) and $25 \mu$ proteinase K (10 mg/ml; Sigma, St Louis, MO, USA) were added to approximately $10 \mathrm{mg}$ of ST. The mixture was then vigorously agitated and incubated at $65^{\circ} \mathrm{C}$ for 30 minutes or until complete dissociation of the ST fragments. The enzymatic reaction was stopped by incubation at $95^{\circ} \mathrm{C}$ for $10 \mathrm{~min}$ utes and samples were centrifuged at $10,000 \mathrm{~g}$ for 5 seconds. DNA was extracted on the MagNA Pure instrument using the MagNA Pure LC DNA isolation kit-Large Volume, in accordance with the manufacturer's instructions.

\section{Broad-range PCR amplification of 165 rRNA genes}

The full-length 16S rRNA gene was amplified from extracted DNA with broad range primers (BAc08F: 5'-AGAGTTTGATCCTGGCTCAG-3'; and Uni 1390R: 5'-GACGGGCGGTGTGTA CAA-3'), targeting the region corresponding to 
Table 1

\begin{tabular}{|c|c|c|c|c|}
\hline $\begin{array}{l}\text { Diagnosis } \\
\text { (patients; } \mathrm{n}=28 \text { ) }\end{array}$ & $\begin{array}{l}\text { Median disease duration } \\
\text { (months [range]) }\end{array}$ & $\begin{array}{l}\text { Actual age or median age } \\
\text { (years [range]) }\end{array}$ & $\begin{array}{l}\text { Sex or sex ratio } \\
(\mathrm{M} / \mathrm{F})\end{array}$ & Clinical details \\
\hline $\operatorname{ReA}(n=6)$ & $2(1-6)$ & $35(20-50)$ & $5: 1$ & \\
\hline 1 & & 28 & M & $\begin{array}{l}\text { Sexually acquired ReA;Ct lgG positive serologya; } \\
\text { Ct-positive PCR }\end{array}$ \\
\hline 2 & & 22 & M & Sexually acquired $\operatorname{ReA} ; C t \lg G$ positive ${ }^{a}$ \\
\hline 3 & & 40 & $\mathrm{~F}$ & Sexually acquired $\operatorname{ReA} ; C t \lg G$ positive serologya \\
\hline 4 & & 20 & M & $\begin{array}{l}\text { Sexually acquired ReA; } C t \lg G \text { positive serologya; } \\
\text { B27+c }\end{array}$ \\
\hline 5 & & 50 & M & $\begin{array}{l}\text { Sexually acquired ReA; Ct lgG positive serologya; } \\
\text { Ct positive PCR } ; \text { B } 27+\end{array}$ \\
\hline 6 & & 30 & M & Sexually-acquired ReA; $C t \lg G$ positive serology \\
\hline$U A(n=9)$ & $25(2-60)$ & $40(22-59)$ & $5: 4$ & - \\
\hline $\mathrm{RA}(n=7)$ & $66(12-228)$ & $44(39-53)$ & $2: 5$ & - \\
\hline$O A(n=6)$ & $14(12-24)$ & $58(44-70)$ & $5: 1$ & - \\
\hline
\end{tabular}

aSerology positivity was determined by microimmunofluorescence assay. ${ }^{\mathrm{b}} \mathrm{Chlamydia}$ PCR in genital swabs was determined by Cobas Amplicor PCR assay (Roche Diagnostics Molecular Systems, Inc, CA, USA). CHLA-B27 positivity was determined using a microcytotoxicity assay. Ct, Chlamydia trachomatis; RA, rheumatoid arthritis; ReA, reactive arthritis; OA, osteoarthritis; UA, undifferentiated arthritis.

nucleotides 8 to 27 and 1,390 to 1,407 of the Escherichia coli $16 \mathrm{~S}$ rRNA gene $[28,29]$. DNA was amplified in $50 \mu \mathrm{l}$ reaction mixtures, each containing $1 \times$ Ex Taq Buffer (Takara Ex taq, Otsu, Shiga, Japan), $0.2 \mathrm{mmol} / \mathrm{l}$ of each primer, $2.5 \mathrm{mmol} / \mathrm{l}$ of each DNTP, $2 \mathrm{mmol} / \mathrm{l} \mathrm{MgCl}$ and 1.25 units of Takara Ex Taq DNA polymerase (Takara Ex taq, Otsu, Shiga, Japan. T4 Gene 32 Protein ( $5 \mu \mathrm{g} / \mu \mathrm{l}$; USB Corp, Cleveland, Ohio) was added to the PCR mix followed by $2.5 \mu$ of DNA extract. PCR was performed as follows: initial denaturation at $94^{\circ} \mathrm{C}$ for $5 \mathrm{~min}$ utes, followed by 30 cycles of denaturation at $94^{\circ} \mathrm{C}$ for 1 minute, primer annealing at $59^{\circ} \mathrm{C}$ for 1 minute and extension at $72^{\circ} \mathrm{C}$ for 1.5 minutes. The final elongation step was extended to 15 minutes. PCR was carried out in a Gene-Amp PCR System 9700 (Applied Biosystems, Foster City, CA, USA). All extracts were tested undiluted, diluted $1: 10$ and 1:20, with or without T4 Gene 32 Protein, to avoid false-negative results. The T4 Gene 32 Protein was used to increase the yield of PCR products [30-32].

Pure DNA from either E. coli or C. trachomatis was used as a positive control for the broad-range PCR screening system. Amplification products were visualized on ethidium bromidestained 1\% Seakem GTG agarose gel (Tebu-bio, Le Perray en Yvelines, France).

Precautionary measures were taken to prevent DNA contamination during DNA extraction and manipulation. These included pipeting PCR components under a laminar flow of sterile air, using only sterile equipments, dedicated pre-PCR and post-PCR rooms, and dedicated sets of pipettes, disposable gloves, laboratory coats and non-reusable waste containers. Reagents and PCR primers were aliquoted to prevent frequent handlings. DNA extraction was performed in two separated biological hoods, which were cleaned before and after each sample preparation with $5 \%$ bleach solution. Gloves were changed between each tissue sample. DNA contamination was avoided using aeroguard filter tips (TipOne; Starlab, Bagneux, France) and individually self-sealing PCR tubes (Starlab, Bagneux, France), irradiated with UV light at $254 \mathrm{~nm}$ for 10 minutes to inactivate extraneous DNA. Negative controls (water during the amplification step and an uninfected mouse heart tissue sample during the extraction protocol) were included every five samples for each experiment to monitor potential contamination. If amplification occurred in any of the negative controls, the PCR was repeated [33]. All samples were amplified in duplicate to allow a large number of clones to be sequenced.

\section{Cloning, DNA sequencing and sequence analysis}

The 16S rDNA amplicons were inserted into a vector using a cloning kit (pGEM-T vector; Promega, Madison, WI, USA), in accordance with the manufacturer's instructions. 16S rDNAcontaining clones were grown in Nunc microtiter plates containing $150 \mu$ l of $2 \times$ Luria-Bertani medium supplemented with $10 \%$ glycerol and ampicillin $(100 \mu \mathrm{g} / \mathrm{ml})$. Insert amplifications were performed using the GE Healthcare amplification kit by the RCA (rolling circle amplification) method (GE Healthcare, formerly Amersham). Amplicons were purified and then sequenced using the commercial BigDye Terminator v3.1 kit (Applied Biosystems) on a 3730XL sequencer (Applied Biosystems). The resulting $16 \mathrm{~S}$ rDNA clones sequences were compared to sequences in the European Molecular Biology Laboratory (EMBL) databases using BLAST (basic local align- 
ment search tool) and then checked for chimera using ribosomal database project II software [34].

\section{Stastistical analysis}

Data were compared by Fisher's exact test using Epi Info software, version 6.04a (Centers for Disease Control and Prevention, Atlanta, GA, USA). $P<0.05$ was considered to be statistically significant.

\section{Results \\ PCR positivity by the broad-range PCR amplification system}

Because PCR and extraction controls were negative, our results could be interpretated accurately. Amplification products of the 16S rRNA gene were generated from 21 of the 28 ST samples (75\%) using broad-range PCR. Amplicons were detected in all samples from the six patients with $\operatorname{ReA}(100 \%)$ and nine with UA (100\%). In the control group, bacterial $16 \mathrm{~S}$ rDNA was amplified in ST samples from three of the seven patients with RA (43\%) and from three of the six with OA (50\%). Accordingly, the proportion of ST samples from ReA and $U A$ patients yielding positive PCR results was significantly higher than that of positive ST samples from control group patients (100\% [15/15] versus 46.2\% [6/13]; $P=0.001$ ). Additionally, $\mathrm{ReA}$ and UA samples exhibited a higher bacterial DNA load, as indicated by the signal intensity of the PCR products (Table 2). To enhance the spectrum of DNA from bacterial species detected, at least 24 individual clones from each sample were sequenced. Additional sequencing was performed if problems were encountered during the cloning of nonspecific or partial $16 \mathrm{~S}$ rDNA products. In general, poorer DNA profiles of bacterial species were obtained from tissue samples that gave weak PCR signals (Table 2).

\section{Bacterial 16S rDNA sequences identified in synovial tissue samples}

A broad range of DNAs from bacterial species was detected in each ST sample (Table 3). Only good quality sequences, with length $\geq 1,000$ nucleotides, were analyzed. Most bacterial sequences had $\geq 97 \%$ sequence similarity with cultivated or uncultured bacteria. The per cent similarity to best fit sequence from the database, the accession number and the sequence length are listed in Table 4.

DNA from a total of 68 individual bacterial species were detected in ST samples from the patients with ReA and UA, and 12 DNAs from different bacteria were identified in the control ST samples. Additionally, DNAs from 20 bacterial species were detected in both study and control samples from patients with ReA, UA, RA, or OA. Therefore, these organisms are probably common in joint diseases (Table 4). Many sequences were from commensal bacteria, in particular those normally found in the skin or the intestinal tract (Propionibacterium acnes, $E$. coli and other coliform bacteria). We also detected bacterial DNAs from mucosal bacterial flora such as streptococci, Actinomycetes and Neisseria, and DNAs from opportunistic pathogens such as Stenotrophomonas maltophilia, Alcaligenes faecalis, Achromobacter xylosoxidans and Acinetobacter spp. in a number of samples. We found DNAs from organisms that are commonly identified as triggering $\operatorname{ReA}$, such as Shigella flexneri and Shigella sonnei $[35,36]$, in $33.33 \%$ of ReA and UA samples, but not in control samples. S. sonnei DNA was detected in samples from one $\mathrm{ReA}$ and one UA patient. S. flexneri DNA was detected in samples from two patients with $\operatorname{ReA}$ and one with UA. DNA from Propionibacterium acnes - an arthritogenic agent involved in SAPHO (synovitis, acne, pustulosis, hyperostosis, and osteitis) syndrome, which is an oligoarthritis associated with acnes and pustilosis $[37,38]$ - was detected in ReA and UA samples. Detection of this bacterium-derived DNA was associated with S. sonnei (patient 3) and with S. flexneri (patient 5). Patient 5 exhibited pustilosis lesions associated with an urogenital infection-associated arthritis. Despite there being no history of septic arthritis in his clinical records, we detected DNAs from Staphylococcus aureus and streptococcal species in the ST sample from patient 7 (a patient with UA).

No genitourinary tract bacterial sequences (for example, C. trachomatis) were detected in our patient samples. This was unexpected, especially in ReA patients with a preceding urogenital infection. We also detected DNAs of several bacterial species that have previously been described in human infections but not in arthritis (Table 4). These include DNAs from Bosea vestrisii, Brevundimonas diminuta, Corynebacterium tuberculostearicum, Corynebacterium durum, Microbacterium oxydans, Oxalobacter spp., Paracoccus yeei, Leptotrichia spp., Enterobacter hormachei, Enterobacter cecorum, Serratia proteamasculans and Ralstonia spp. Most of these DNAs were mostly detected in one or more ReA or UA samples but not in control group samples. DNAs from Serratia proteamasculans and Ralstonia spp were also detected in the control group. Additionally, we detected DNAs from several bacterial species that have not previously been reported in human infection (Table 4). Aquabacterium commune, Blastococcus spp., Halomonas spp., Leucobacter lutti, Novosphingobium spp., Pedomicrobium australicum, Variovorax spp., Sphingobacterium asaccharolytica and manganese-oxidizing bacteria were identified from ReA and UA patient samples. We detected DNA from Caulobacter leidyia, Curvibacter gracilis and Rhodococcus fasciens in control group samples. We detected in ST samples some bacterial DNA sequences not previously characterized by rDNA sequencing since they exhibit less than $97 \%$ similarity to known database sequences. For example, DNA from the candidate division OP10 bacterium was detected in three ReA patients and four UA patients, but not in control group. We could find no clear association between the presence of these bacterial DNA and clinical symptoms. 
Table 2

\begin{tabular}{|c|c|c|c|}
\hline Patient & PCR intensity score ${ }^{a}$ & Total number of clones sequenced & Number of obtained bacterial DNA sequences \\
\hline \multicolumn{4}{|l|}{$\operatorname{ReA}$} \\
\hline 1 & ++++ & 47 & 38 \\
\hline 2 & +++ & 96 & 36 \\
\hline 3 & +++ & 84 & 50 \\
\hline 4 & +++ & 104 & 48 \\
\hline 5 & +++ & 34 & 26 \\
\hline 6 & ++++ & 24 & 24 \\
\hline \multicolumn{4}{|l|}{ UA } \\
\hline 7 & ++ & 105 & 48 \\
\hline 8 & ++ & 114 & 41 \\
\hline 9 & ++ & 72 & 42 \\
\hline 10 & ++ & 75 & 25 \\
\hline 11 & ++ & 96 & 46 \\
\hline 12 & ++ & 74 & 34 \\
\hline 13 & ++ & 118 & 42 \\
\hline 14 & ++ & 60 & 28 \\
\hline 15 & ++ & 101 & 49 \\
\hline \multicolumn{4}{|l|}{$\mathrm{RA}$} \\
\hline 16 & ++ & 48 & 40 \\
\hline 17 & + & 96 & 35 \\
\hline 18 & + & 48 & 11 \\
\hline \multicolumn{4}{|l|}{ OA } \\
\hline 19 & + & 48 & 31 \\
\hline 20 & + & 72 & 18 \\
\hline 21 & + & 48 & 5 \\
\hline
\end{tabular}

aSemi-quantification of intensity of the 16S rDNA amplification products, visualized using ethidium bromide staining after agarose gel electrophoresis: ' + ' indicates barely visible band, and ' ++++ ' indicates maximal intensity. OA, osteoarthritis; RA, rheumatoid arthritis; ReA, reactive arthritis; UA, undifferentiated arthritis.

\section{Discussion}

We investigated the presence of bacterial DNA in ST samples from patients with ReA and UA, using $16 \mathrm{~S}$ rRNA PCR, cloning and sequencing. This is, to our knowledge, the first study using the full-length 16S rRNA gene as a target for broad-spectrum PCR to detect bacterial DNA in synovial samples.

We extracted DNA from ST samples from 28 patients with arthritis. We found bacterial DNA in 21 (75\%) of these patients, using stringent sterility and anti-contamination techniques. Previous studies, using PCR assays with universal 16S rDNA primers, identified lower proportions of human synovial samples containing bacterial DNA: $42 \%$ of synovial fluid and ST samples in one study [18], and 10\% of ST samples in another [17]. Our high proportion of bacterial DNA in ST sam- ples from our patients may be due to the use of the primer pair (Bac08F/Uni1390R) as well as the use of the T4 Gene 32 Protein, which may increase the yield of PCR products [3032].

Sequence analysis of the PCR-positive samples revealed the presence of a mixture of bacterial DNA in synovial samples from patients with ReA, UA, RA or OA. These findings are similar to those reported in previous studies [12,14,17,39]. A significant disadvantage of broad-range PCR is the tendency to yield false-positive results $[33,40]$. In fact, we undertook stringent precautionary measures at each step (as presented in Materials and methods; see above) to prevent contamination. In addition, the MagNAPure system used is a rapid, closed, automated and standardized method for DNA extraction, elim- 
Table 3

Details of bacterial species-derived DNA sequences identified in each patient*

Patient Total number of bacterial DNA sequences identified in each patient DNA sequences

$\operatorname{ReA}$

138

236

350

4

UA
$9 \times$ Escherichia coli, $5 \times$ Propionibacterium acnes, $4 \times$ Stenotrophomonas maltophilia, $3 \times$ proteobacterium, $2 \times$ Afipia genosp, $2 \times$ Escherichia spp., $2 \times$ swine manure bacterium, $2 \times$ uncultured $\beta$ proteobacterium, $2 \times$ uncultured candidate division OP10 bacterium, $1 \times$ Alcaligenes faecalis, $1 \times \alpha$ proteobacterium, $1 \times$ Brevundimonas diminuta, $1 \times$ Pseudomonas sp., $1 \times$ Ralstonia sp., $1 \times$ Shigella sp., $1 \times$ Sphingomonas sp.

$14 \times$ Escherichia coli, $5 \times$ Bradyrhizobium elkanii, $4 \times$ swine manure bacterium, $3 \times$ Sphingomonas asaccharolytica, $2 \times$ Pseudomonas poae, $2 \times$ Ralstonia spp., $2 \times$ uncultured Flavobacterium spp., $2 \times$ uncultured Sphingobacterium spp., $1 \times$ Flavobacterium mizutaii, $1 \times$ Pseudomonas $\mathrm{sp}$

$8 \times$ Alcaligenes faecalis, $7 \times \gamma$ proteobacterium, $7 \times$ Stenotrophomonas maltophilia, $6 \times$ Rhodococcus spp., $6 \times$ swine manure bacterium, $5 \times$ Shigella sonnei, $5 \times$ Propionibacterium acnes, $4 \times$ unclassified proteobacteria, $2 \times$ Serratia proteamaculans

$25 \times$ Aquabacterium commune, $4 \times$ Afipia genosp, $4 \times$ swine manure bacterium, $2 \times$ Escherichia spp., $2 \times$ $\gamma$ proteobacterium, $2 \times$ Propionibacterium acnes, $2 \times$ Stenotrophomonas maltophilia, $1 \times$ Acinetobacter baumannii, $1 \times \alpha$ proteobacterium, $1 \times$ Flavobacterium mizutaii, $1 \times$ Ralstonia sp., $1 \times$ Shigella flexneri, 1 $\times$ Variovorax sp., $1 \times$ uncultured candidate division OP10 bacterium

$6 \times$ Aquabacterium commune, $6 \times \gamma$ proteobacterium, $3 \times$ Afipia genosp, $2 \times$ Propionibacterium acnes, 2 $\times$ Ralstonia spp., $2 \times$ swine manure bacterium, $1 \times$ Shigella flexneri, $1 \times$ Shigella sp., $1 \times$ Staphylococcus haemolyticus, $1 \times$ Stenotrophomonas maltophilia, $1 \times$ uncultured eubacterium

$10 \times$ Escherichia coli, $3 \times \gamma$ proteobacterium, $2 \times$ Leucobacter luti, $2 \times$ Staphylococcus spp., $2 \times$ swine manure bacterium, $2 \times$ uncultured candidate division OP10 bacterium, $1 \times$ Ralstonia sp., $1 \times$ Stenotrophomonas maltophilia, $1 \times$ uncultured Sphingobacterium sp. 
Table 3 (Continued)

Details of bacterial species-derived DNA sequences identified in each patient ${ }^{*}$

1234

1342

1428

1549
$13 \times$ Escherichia coli, $4 \times$ Corynebacterium coyleae, $3 \times$ Sphingomonas spp., $2 \times \gamma$ proteobacterium, $2 \times$ Ralstonia spp., $2 \times$ Shigella spp., $2 \times$ swine manure bacterium, $2 \times$ uncultured Sphingobacterium spp., 1 $\times$ Flavobacterium mizutaii, $1 \times$ Klebsiella sp., $1 \times$ Propionibacterium acnes, $1 \times$ unclassified enterobacteria

$18 \times$ Escherichia coli, $4 \times$ uncultured Sphingobacterium spp., $3 \times$ Stenotrophomonas maltophilia, $2 \times$ Aeromonas spp., $2 \times$ Flavobacterium mizutaii, $2 \times$ gamma proteobacterium, $2 \times$ Ralstonia spp., $2 \times$ uncultured candidate division OP10 bacterium, $1 \times$ Alcaligenes faecalis, $1 \times$ Acinetobacter sp., $1 \times$ Halomonas sp., $1 \times$ Stenotrophomonas sp., $1 \times$ swine manure bacterium, $1 \times$ Sphingomonas sp., $1 \times$ uncultured Flavobacterium sp.

$8 \times$ Escherichia coli, $2 \times$ Bradyrhizobium japonicum, $2 \times \gamma$ proteobacterium, $2 \times \alpha$ proteobacterium, $2 \times$ Stenotrophomonas maltophilia, $2 \times$ Sphingomonas spp., $2 \times$ Corynebacterium durum, $1 \times$ Achromobacter xylosoxidans, $1 \times$ Bacteroidetes bacterium, $1 \times \beta$ proteobacterium, $1 \times$ Bradyrhizobium elkanii, $1 \times$ Novosphingobium spp., $1 \times$ Paracoccus spp., $1 \times$ unclassified Rhodocyclaceae, $1 \times$ uncultured Sphingobacterium sp.

$17 \times$ Escherichia coli, $5 \times$ Shigella spp., $4 \times$ Stenotrophomonas maltophilia, $4 \times$ unclassified Rhodocyclaceae, $3 \times$ swine manure bacterium, $3 \times$ uncultured candidate division OP10 bacterium, $2 \times$ uncultured Sphingobacterium spp., $2 \times$ uncultured Sphingobacterium spp., $2 \times$ Rhodococcus spp., $1 \times$ Alcaligenes sp., $1 \times \alpha$ proteobacterium, $1 \times$ Bradyrhizobium japonicum, $1 \times$ Ralstonia sp., $1 \times$ Flavobacterium mizutaii, $1 \times \gamma$ proteobacterium, $1 \times$ Pedomicrobium australicum

RA

1640

$15 \times$ Escherichia coli, $5 \times$ swine manure bacterium, $4 \times$ Ralstonia spp., $3 \times$ uncultured Flavobacterium spp., $2 \times$ Acinetobacter spp., $2 \times$ Antarctic bacterium, $2 \times$ Flavobacterium mizutaii, $1 \times$ Actinomyces naeslundii, $1 \times$ Alcaligenes faecalis, $1 \times$ Bacteroidetes bacterium, $1 \times$ Caulobacter sp., $1 \times$ Corynebacterium aurimucosum, $1 \times$ Shigella sp., $1 \times$ uncultured $\alpha$ proteobacterium

$17 \quad 35$

$6 \times$ Escherichia coli, $5 \times$ Shigella spp., $4 \times$ Bradyrhizobium elkanii, $4 \times$ uncultured Sphingobacterium spp., $3 \times$ Ralstonia spp., $3 \times$ uncultured Flavobacterium spp., $2 \times \gamma$ proteobacterium, $2 \times$ swine manure bacterium, $1 \times$ Alcaligenes sp., $1 \times$ Caulobacter sp., $1 \times$ Pseudomonas sp., $1 \times$ Rhodococcus fascians, 1 $\times$ Serratia proteamaculans, $1 \times$ Streptococcus thermophilus

1811

$7 \times$ Escherichia coli, $2 \times$ Stenotrophomonas maltophilia, $1 \times \gamma$ proteobacterium, $1 \times$ Ralstonia sp.,

OA

$7 \times$ Escherichia coli, $7 \times$ swine manure bacterium, $5 \times$ Alcaligenes faecalis, $4 \times$ Pseudomonas poae, $3 \times$ Bradyrhizobium elkanii, $2 \times$ Stenotrophomonas maltophilia, $1 \times$ Caulobacter leidyia, $1 \times$ Curvibacter gracilis, $1 \times \gamma$ proteobacterium

$7 \times$ Escherichia coli, $7 \times$ uncultured Flavobacterium spp., $2 \times$ uncultured Sphingobacterium spp., $1 \times$ uncultured delta proteobacterium, $1 \times$ Shigella sp.

$2 \times$ Alcaligenes spp., $1 \times$ Achromobacter xylosoxidans, $2 \times$ Brucellaceae bacterium

inating many manual steps and thus minimizing the risk for cross-contamination. PCR and extraction controls consistently yielded negative results; thus, the PCR products detected in positive samples should derive only from tissue-associated bacterial rRNA genes.

Most commensal and environmental bacterial 16S rDNA sequences detected in our broad-range PCR analysis of syn- ovial samples belong to species identified in previous studies $[12,14,17,18]$. Some of these were found in both the patients and control group (for instance, Stenotrophomonas maltophilia and E. coli), implying that their presence in the synovium is not disease specific; rather, they are likely to be opportunistic colonizers of tissue that was already diseased. $E$. coli DNA was detected in synovial samples from several patients (three with $\operatorname{ReA}$, eight with UA, three with RA and two 
Arthritis Research \& Therapy Vol 10 No 2 Siala et al.

Table 4

Bacterial species identified by sequencing of cloned 165 rDNA

Bacterium-derived DNA identified in ST Number of patients in whom bacterial Accession numbera Length of the sequence ${ }^{\mathrm{b}}$ \% Similarityc samples DNAs were detected

Bacteria identified in ReA and UA patients $(n=68)$

Bacteria previously detected in arthritis

\begin{tabular}{|c|c|c|c|c|}
\hline Acinetobacter baumannii & $(1 \mathrm{Re} A)$ & AY738400 & 1,384 & 99.86 \\
\hline Acinetobacter schindleri & $(1 \cup A)$ & AJ278311 & 1,367 & 98.83 \\
\hline Actinomyces sp. & $(1 \cup A)$ & AY008315 & 1,420 & 98.73 \\
\hline Aeromonas sp. & $(1 \cup A)$ & U88656 & 1,396 & 99.36 \\
\hline Aeromonas sp. & $(2 \cup A)$ & AF099027 & 1,336 & 98.58 \\
\hline Afipia genosp 7 & $(1 \cup A)$ & U87773 & 1,336 & 97.38 \\
\hline Afipia genosp 9 & $(1 \mathrm{Re} A)$ & U87779 & 1,335 & 99.62 \\
\hline Afipia genosp 9 & $(1 \mathrm{Re} A)$ & U87775 & 1,256 & 97.00 \\
\hline Afipia genosp 9 & $(1 \mathrm{Re} A)$ & U87777 & 1,337 & 99.55 \\
\hline Corynebacterium coyleae & $(1 \cup A)$ & X96497 & 1,360 & 99.04 \\
\hline Escherichia coli & $(1 \mathrm{Re} A)$ & AP009048 & 1,389 & 99.71 \\
\hline Escherichia sp. & $(2 \mathrm{ReA})$ & DQ337503 & 1,390 & 99.71 \\
\hline Klebsiella sp. & $(1 \cup A)$ & U32868 & 1,387 & 99.57 \\
\hline Neisseria flava & $(1 \cup A)$ & AJ239301 & 1,338 & 98.43 \\
\hline Paracoccus sp. & $(1 \mathrm{UA})$ & AY745834 & 1,308 & 99.92 \\
\hline Propionibacterium acnes & $(1 \mathrm{Re} A+2 \mathrm{UA})$ & AB108477 & 1,377 & 100.00 \\
\hline Pseudomonas sp. & $(1 \cup A)$ & DQ079062 & 1,388 & 98.63 \\
\hline Ralstonia sp. & $(1 \mathrm{ReA})$ & DQ227340 & 1,382 & 100.00 \\
\hline Rhodococcus sp. & $(2 \cup A)$ & AF420412 & 1,365 & 99.85 \\
\hline Shigella flexneri & $(2 \operatorname{Re} A+1 U A)$ & X96963 & 1,389 & 99.71 \\
\hline Shigella sonnei & $(1 \mathrm{ReA})$ & X96964 & 1,389 & 99.86 \\
\hline Shigella sonnei & $(1 \mathrm{UA})$ & CP000038 & 1,390 & 97.70 \\
\hline Sphingomonas sp. & $(2 \cup A)$ & AJ864842 & 1,329 & 99.77 \\
\hline Staphylococcus aureus & $(1 \cup A)$ & L37597 & 1,400 & 99.93 \\
\hline Staphylococcus haemolyticus & $(1 \mathrm{ReA})$ & AP006716 & 1,400 & 99.93 \\
\hline Staphylococcus sp. & $(1 \mathrm{ReA})$ & AJ704792 & 1,400 & 99.72 \\
\hline Staphylococcus sp. & $(1 \cup A)$ & AB177642 & 1,399 & 99.71 \\
\hline Stenotrophomonas sp. & $(1 \cup A)$ & AF409004 & 1,382 & 99.13 \\
\hline Streptococcus infantis & $(1 \cup A)$ & AY485603 & 1,385 & 99.64 \\
\hline Streptococcus mitis & $(2 \cup A)$ & AY005045 & 1,385 & 99.57 \\
\hline Streptococcus sanguinis & $(1 \mathrm{UA})$ & AF003928 & 1,397 & 99.79 \\
\hline
\end{tabular}


Bacteria not previously detected in arthritis

\begin{tabular}{|c|c|}
\hline Bosea vestrisii & $(1 \cup A)$ \\
\hline Brevundimonas diminuta & $(1 \mathrm{Re} A)$ \\
\hline Corynebacterium durum & $(2 \cup A)$ \\
\hline $\begin{array}{l}\text { Corynebacterium } \\
\text { tuberculostearicum }\end{array}$ & $(2 \cup A)$ \\
\hline Enterococcus cecorum & $(1 \mathrm{UA})$ \\
\hline Enterobacter hormaechei & $(1 \cup A)$ \\
\hline Kingella oralis & $(1 \cup A)$ \\
\hline Leptotrichia sp. & $(1 \cup A)$ \\
\hline Microbacterium oxydans & $(1 \cup A)$ \\
\hline Oxalobacter sp. & $(1 \cup A)$ \\
\hline Paracoccus yeei & $(1 \cup A)$ \\
\hline
\end{tabular}

Caulobacter endosymbiont of Tetranychus urticae

\section{$\gamma$ Proteobacterium}

$(1 \mathrm{ReA})$

Manganese-oxidizing

(2 UA)

bacterium

Uncultured $\alpha$ proteobacterium

(1 UA)

Uncultured $\beta$ proteobacterium $\quad(1 \mathrm{ReA})$

AF288302

X87274

AF537593

AJ438044

AF061009

AY995561

L06164

AY008309

AJ717356

AJ496038

AY014169

AF035054

AJ316573

BA000040

AJ302088

AM072819

AB177883

X97693

X81945

Y09639

AB196432

AY162046

AY162053

AF236007

AY753176
1,336

99.70

1,308

99.62

1,364

99.05

1,368

99.71

1,398

99.43

99.64

98.78

99.85

98.69

98.05

99.77

1,309

1,367

99.85

1,357

97.27

1,333

99.17

98.85

98.39

97.00

98.64

$96.14^{\star}$

98.11

99.28

1,383

1,308

99.62

1,332

99.85

1,371

99.71

99.63

1,334

97.42

\section{AY162032}

1,395

99.85

U53824

1,320

97.06

AF445680

1,329

99.78 
Arthritis Research \& Therapy Vol 10 No 2 Siala et al.

Table 4 (Continued)

Bacterial species identified by sequencing of cloned 16S rDNA

Uncultured candidate division $\quad(3 \operatorname{Re} A+4 U A)$

OP10 bacterium

AF418946

1,297

$90.98^{*}$

Uncultured $\gamma$ proteobacterium (1 UA)

AJ318146

1,397

97.35

Uncultured $\gamma$ proteobacterium (1 UA)

AF324537

1,387

99.71

Unclassified

(1 UA)

AY375058

1,391

97.56

Uncultured eubacterium (1 ReA)

AJ292601

1,334

96.93

Uncultured soil bacterium (1 UA)

AF423262

1,295

96.91

Unclassified proteobacteria (1 ReA)

AY820722

1,383

$96.46^{*}$

Unclassified Rhodocyclaceae

(2 UA)

1,388

99.42

Bacteria identified in control group (RA and OA patients; $n=12$ )

Bacteria previously detected in arthritis

$\begin{array}{ll}\text { Actinomyces naes/undii } & (1 \mathrm{RA}) \\ \text { Brucellaceae bacterium } & (1 \mathrm{OA}) \\ \text { Corynebacterium aurimucosum } & (1 \mathrm{RA}) \\ \text { Streptococcus thermophilis } & (1 \mathrm{RA})\end{array}$

AJ234050

1,392

97.84

AY353698

1,333

99.17

AY536427

1,369

99.34

AY188354

1,397

99.36

Bacteria not previously detected in arthritis
Alcaligenes sp.
$(1 \mathrm{OA})$
Caulobacter sp.
(2 RA)

AF430122

1,386

98.63

AJ227775

1,323

99.70

Bacteria not previously detected in humans

$\begin{array}{ll}\text { Caulobacter leidyia } & (1 \mathrm{OA}) \\ \text { Curvibacter gracilis } & (1 \mathrm{OA}) \\ \text { Rhodococcus fascians } & (1 \mathrm{RA})\end{array}$

AJ227812

1,324

100.00

AB109889

1,379

99.71

Y11196

1,365

99.71

Uncultured bacteria

$$
\begin{array}{ll}
\text { Antarctic bacterium } & \text { (1 RA) } \\
\text { Uncultured } \alpha \text { proteobacterium } & (1 \mathrm{RA}) \\
\text { Uncultured } \delta \text { proteobacterium } & (1 \mathrm{RA})
\end{array}
$$

AJ440974

AJ604541

1,324

98.60

AY921777

1,402

97.22

\section{Common bacteriad $^{d}(\mathrm{n}=20)$}

Bacteria previously detected in arthritis

$\begin{array}{ll}\text { Achromobacter xylosoxidans } & (1 \mathrm{UA}+1 \mathrm{OA}) \\ \text { Acinetobacter sp. } & (2 \mathrm{ReA}+1 \mathrm{RA}) \\ \text { Alcaligenes faecalis } & (2 \mathrm{ReA}+1 \mathrm{UA}+1 \mathrm{RA}+1 \mathrm{OA}) \\ \text { Escherichia coli } & (3 \mathrm{ReA}+7 \mathrm{UA}+1 \mathrm{RA}+2 \mathrm{OA}) \\ \text { Escherichia coli } & (3 \mathrm{ReA}+9 \mathrm{UA}+3 \mathrm{RA}+2 \mathrm{OA}) \\ \text { Flavobacterium mizutaii } & (2 \mathrm{ReA}+7 \mathrm{UA}+1 \mathrm{RA}) \\ \text { Pseudomonas sp. } & (2 \mathrm{ReA}+1 \mathrm{UA}+1 \mathrm{RA})\end{array}$

1,378

99.71

Z93442

1,365

99.35

AY548384

1,385

99.93

V00348

1,393

100.00

U00096

1,390

100.00

AJ438175

1,384

$94.44^{*}$

AJ237965

1,376

99.56 
Table 4 (Continued)

\begin{tabular}{|c|c|c|c|c|}
\hline Stenotrophomonas maltophilia & $(3 \operatorname{Re} A+4 U A+1 O A)$ & AJ293470 & 1,395 & 99.93 \\
\hline Shigella sp. & $(2 \mathrm{ReA}+4 \mathrm{UA}+2 \mathrm{RA}+1 \mathrm{OA})$ & DQ337523 & 1,392 & 99.93 \\
\hline \multicolumn{5}{|c|}{ Bacteria not previously detected in arthritis } \\
\hline Alcaligenes sp. & $(1 \mathrm{UA}+1 \mathrm{OA})$ & AY672759 & 1,345 & 99.11 \\
\hline Bradyrhizobium elkanii & $(1 \mathrm{ReA}+2 \mathrm{UA}+1 \mathrm{RA}+1 \mathrm{OA})$ & AY904749 & 1,338 & 99.93 \\
\hline Pseudomonas poae & $(1 \mathrm{Re} A+1 \mathrm{OA})$ & AJ492829 & 1,386 & 99.93 \\
\hline Ralstonia sp. & $(5 \operatorname{Re} A+4 U A+3 R A)$ & AB045276 & 1,388 & 100.00 \\
\hline Serratia proteamaculans & $(1 \mathrm{Re} A+1 \mathrm{RA})$ & AJ233435 & 1,387 & 97.76 \\
\hline \multicolumn{5}{|c|}{ Bacteria not previously detected in humans } \\
\hline \multicolumn{5}{|l|}{ Uncultured bacteria } \\
\hline Bacteroidetes bacterium & $(2 \mathrm{UA}+1 \mathrm{RA})$ & AY395022 & 1,196 & 97.49 \\
\hline$\gamma$ proteobacterium & $(2 \operatorname{Re} A+3 U A+1 O A)$ & AY162042 & 1,399 & 99.88 \\
\hline$\gamma$ proteobacterium & $(4 \mathrm{Re} A+6 \mathrm{UA}+2 \mathrm{RA})$ & AY162068 & 1,397 & 99.93 \\
\hline Swine manure bacterium & $(6 \mathrm{ReA}+5 \mathrm{UA}+2 \mathrm{RA}+1 \mathrm{OA})$ & AY167969 & 1,388 & 100.00 \\
\hline $\begin{array}{l}\text { Uncultured Flavobacterium } \\
\text { sp. }\end{array}$ & $(1 \mathrm{ReA}+4 \mathrm{UA}+2 \mathrm{RA}+1 \mathrm{OA})$ & DQ168834 & 1,193 & 97.15 \\
\hline $\begin{array}{l}\text { Uncultured Sphingobacterium } \\
\text { sp. }\end{array}$ & $(2 \mathrm{ReA}+8 \mathrm{UA}+1 \mathrm{RA}+1 \mathrm{OA})$ & AB076874 & 1,390 & $94.31 *$ \\
\hline
\end{tabular}

Number in brackets after species names indicate the number of patient set from whom bacteria were detected. aAccession number of the bacterial species in the database. bLength of alignment on which the 16S rDNA inserted sequence and the corresponding sequence in the database are similar. cIn the '\% similarity' column, asterisks indicate highligh instances where the \% similarity is below $97 \%$. ${ }^{2}$ The 'Common bacteria' row shows the bacteria identified in ReA, UA, RA and OA patients. OA, osteoarthritis; RA, rheumatoid arthritis; ReA, reactive arthritis; ST, synovial tissue; UA, undifferentiated arthritis.

with OA). Other studies have demonstrated that commensal organisms such as E. coli, widely distributed in the human gut, can colonize inflamed joints [41-44]. However, a better understanding of the contribution made by intestinal microflora to human biology is needed to elucidate the potential role played by microflora in the pathogenesis of $\operatorname{ReA}[41-44]$.

We detected DNAs of some bacteria that have not previously been described in human synovial samples, such as Blastococcus spp., Leucobacter lutti, Halomonas spp., Rhodococcus fascians and manganese-oxidizing bacteria (Table 4). These organisms have an environmental source (soil, plant and water). Other $16 \mathrm{~S}$ rRNA gene sequences showing less than $97 \%$ sequence similarity with bacterial sequences from the EMBL database and affiliated with noncultivated bacteria were detected. Thus, we found DNAs from uncultured candidate division OP10 bacteria in ReA and UA samples, but not in control samples. However, the synovium is probably an interfacial zone that can be colonized by bacterial DNAs originating from the environment and the endogenous microflora [37]; indeed, only a proportion of resident commensal micro-organisms in the gut have been identified [44].
Our approach of cloning and near full-length sequencing of bacterial 16S rDNA might confirm the presence of such DNAs of bacteria not considered to be human pathogens in the synovium. Their significance remains unclear, however, and further investigations will be required to determine the pathogenic relevance of these findings.

We detected DNA from Shigella flexneri and Shigella sonnei - micro-organisms that are known to trigger ReA - in $\operatorname{ReA}$ and/or UA samples but not in control samples. Shigella DNA positive patients had no clinical signs of previous intestinal infection with an enteric organism. These patients may have been asymptomatic, or the preceding gastrointestinal symptoms may have been mild and overlooked by the patients [6]. It is possible that enteric organisms may move from asymptomatic primer sites of infection to the synovium in such patients [6]. Most Shigella ReA cases are caused by S. flexneri [35], but sporadic cases associated with $S$. sonnei and $S$. dysenteriae have been described $[4,35]$. The most recent published case of $S$. sonnei related $\operatorname{ReA}$ was attributed to sexual transmission of the pathogen [36]. In our study, we detected $S$. sonnei DNA in one ReA patient presenting with an urogenital 
infection, which is consistent with the possibility that this species could be related to sexual transmission.

Propionibacterium acnes sequences were detected in synovial samples of one $\operatorname{ReA}$ patient with pustular lesions and two UA patients in whom we did not detect any other causative bacteria derived DNA. Thus, the presence of $P$. acnes DNA in these patients is likely to be either disease specific or due to opportunistic colonization of the inflamed joints. This bacterium is part of the normal skin flora. It was recently identified in articular samples from patients with SAPHO (synovitis, acne, pustulosis, hyperostosis, and osteitis) syndrome, which is often regarded to be a form of spondyloarthropathy, suggesting an infectious origin of this syndrome $[37,38]$. Our findings also suggest that this organism can access the joints.

ReA-related genitourinary bacterial species, including chlamydial sequences, were not detected in any patient samples, despite the large number of clones sequenced and analyzed for each sample. Thus, it is possible that not all bacterial DNAs present within the joint were detected. Indeed, even for arthritic patients with related urogenital infections, the detection of genital infectious agents by broad-range PCR may have been masked by the presence of other bacterial DNAs. Thus, bacteria appear to move from various anatomic sites such as gut to the joints. This is consistent with the detection of $E$. coli sequence in many of the synovial samples. In enteric $\operatorname{Re} A$, active bowel inflammation affects the barrier function of the gut wall, allowing gut flora to access systemic sites [45]. Moreover, most of the patients were taking nonsteroidal drugs, which can impair gut permeability and mucosal competence.

We have shown that sequences from bacterial species that are known to be involved in the onset of arthritis represented a minority of the sequences detected in ST samples from patients with ReA. In addition, their presence was associated with DNAs from commensal and environmental bacterial flora. This raises the question about the role that this variety of intraarticular bacterial DNA plays in the pathogenesis of $\operatorname{ReA}$ and other forms of arthritides. However, detection of bacterial DNAs in the ST of patients with arthritis does not necessarily reflect the presence of complete bacterial genome, the presence of infectious bacteria or the potential of bacterial replication, or indicate whether detected DNA is related to the synovial pathology [2]. Within this context, the presence of multiple bacterial DNAs in patient joints does not substantiate a multibacterial infection that could ensue in these patients. Our detection of bacterial DNA in synovia of both control and study patient samples may indicate that a low level of 'background' bacterial DNA is usually present in synovial material and that such DNAs do not necessarily cause synovitis $[17,46]$. Such a variety of bacterial DNA could be due to the passive transfer of various bacterial products within phagocytic cells to the inflamed joint. Consistent with this, bacterial fragments have previously been detected - using immunohis- tochemical techniques - in macrophages from spleen of rats and humans and in synovium-derived macrophages from patients with various arthropathies $[41,47,48]$. Nonspecific migration of inflammatory cells containing bacterial particles into synovium could promote synovial inflammation [17]. On the other hand, bacterial DNA itself might trigger an immune response, and thus may induce synovitis. It has been shown that experimental intra-articular injection of some bacterial DNA (Escherichia coli, Staphylococcus aureus) or simply of nonmethylated $\mathrm{CpG}$ motifs is sufficient to trigger arthritis in mice [49-51]. The hypothesis is that bacterial DNA may be directly responsible for part of the synovial inflammation. This merits further investigations in humans, particularly to assess whether the quantity of bacterial DNA required to induce arthritis is comparable with the 'inoculum' observed in vitro in $\operatorname{Re} A$ and other arthritides.

\section{Conclusion}

Broad-range PCR, sequencing and cloning are essential techniques for the characterization of the microbial environment in joints. This is the first study to use a broad-range 1,400 base pair $16 \mathrm{~S}$ rDNA PCR coupled to automated DNA extraction to identify bacterial nucleic acid present in the joints of patients with $\operatorname{ReA}$ and other forms of arthritis. Our study provides a potential overall picture of the detailed presence of bacterial DNA in arthritic joint. Cloning procedures allowed the identification of known ReA-triggering organisms, unknown pathogens, and potentially novel bacterial species not previously associated with $\operatorname{ReA}$ and other forms of arthritis

\section{Competing interests}

The authors declare that they have no competing interests.

\section{Authors' contributions}

MS performed the experimental work, analyzed the data and wrote the manuscript. RG conceived of the study, performed the design and coordination of the study, analyzed the data, and revised the manuscript. HF, MY, SB, NB and SS made pathological diagnosis, conducted sampling procedures, and performed clinical and rheumatological data analyses. AZ, CB and EC conducted assessment of Chlamydia trachomatis serology and DNA extraction. BJ and JS participated in the design and coordination of the study, and drafted the manuscript. $\mathrm{AH}$ and $\mathrm{AS}$ analyzed microbiological and sequencing data, and revised the manuscript. All authors read and approved the final manuscript.

\section{Acknowledgements}

We thank Sebastien Chaussonneri and Sonda Guermazi (CEA-Genoscope) for help with sequence analysis and for technical assistance. We also thank llhem Cheour (Tunis), Nihel Meddeb (Tunis), Mohamed Moalla (Tunis) and Imed kolsi (Sfax) for providing patient synovial samples. 


\section{References}

1. Hamdulay S, Glynne SJ, Keat A: When is arthritis reactive? Postgrad Med J 2006, 82:446-453.

2. Sigal LH: Synovial fluid-polymerase chain reaction detection of pathogens: what does it really mean? Arthritis Rheum 2001, 44:2463-2466.

3. Toivanen A, Toivanen P: Reactive arthritis. Best Pract Res Clin Rheumatol 2004, 18:689-703.

4. Hannu T, Inman R, Granfors K, Leirisalo-Repo M: Reactive arthritis or post-infectious arthritis? Best Pract Res Clin Rheumatol 2006, 20:419-433.

5. Braun J, Laitko S, Treharne J, Eggens U, Wu P, Distler A, Sieper J: Chlamydia pneumoniae -a new causative agent of reactive arthritis and undifferentiated oligoarthritis. Ann Rheum Dis 1994, 53:100-105

6. Gaston JSH, Mark S, Lilli Crap MS: Arthritis associated with enteric infection. Best Pract Res Clin Rheumatol 2003, 17:219-239.

7. Wollenhaupt $\mathrm{J}$, Zeidler $\mathrm{H}$ : Undifferentiated arthritis and reactive arthritis. Curr Opin Rheumatol 1998, 10:306-313.

8. Hitchon CA, Peschken CA, Shaikh S, El-Gabalawy HS: Early undifferentiated arthritis. Rheum Dis Clin North Am. 2005, 31:605-626.

9. Bas S, Griffais R, Kvien TK, Glennas A, Melby K, Vischer TL: Amplification of plasmid and chromosome Chlamydia DNA in synovial fluid of patients with reactive arthritis and undifferentiated seronegative oligoarthropathies. Arthritis Rheum 1995, 38:1005-1013.

10. Gaston JSH, Cox C, Granfors K: Clinical and experimental evidence for persistent Yersinia infection in reactive arthritis. Arthritis Rheum 1999, 42:2239-2242.

11. Hannu T, Puolakkainen M, Leirisalo-Repo M: Chlamydia pneumoniae as a triggering infection in reactive arthritis. Rheumato/ogy (Oxford) 1999, 38:411-414.

12. Cox CJ, Kempsell KE, Gaston JSH: Investigation of infectious agents associated with arthritis by reverse transcription PCR of bacterial rRNA. Arthritis Res Ther 2003, 5:R1-R8.

13. Schumacher H, Arayssi T, Branigan P, Gerard HC, Klippel J, Pando J, Getsy J, Bulbul R, Yarboro C, Rothfuss S, et al.: Surveying for evidence of synovial Chlamydia trachomatis by polymerase chain reaction (PCR). A study of 411 synovial biopsies and synovial fluids [abstract]. Arthritis Rheum 1997:S270.

14. Kempsell KE, Cox CJ, Hurle M, Wong A, Wilkie S, Zanders ED, Gaston JSH, Crowe JS: Reverse transcriptase-PCR analysis of bacterial rRNA for detection and characterization of bacterial species in arthritis synovial tissue. Infect Immun. 2000, 68:6012-6026.

15. Schaeverbeke T, Gilroy CB, Bebear C, Dehais J, Taylor-Robinson D: Mycoplasma fermentans, but not $M$ penetrans, detected by PCR assays in synovium from patients with rheumatoid arthritis and other rheumatic disorders. J Clin Pathol 1996, 49:824-828.

16. Olmez N, Wang GF, Li Y, Zhang HD, Schumacher HR: Chlamydial nucleic acids in synovium in osteoarthritis: what are the implications? J Rheumatol 2001, 28:1874-1880.

17. Gérard HC, Wang Z, Wang GF, El-Gabalawy H, Goldbach-Mansky $\mathrm{R}$, Li Y, Majeed W, Zhang $\mathrm{H}$, Ngai N, Hudson AP, Schumacher HR: Chromosomal DNA from a variety of bacterial species is present in synovial tissue from patients with various forms of arthritis. Arthritis Rheum 2001, 44:1689-1697.

18. Wilbrink B, Vanderheijden IM, Schouls LM, Vanembden JDA, Hazes JMW, Breedveld FC, Tak PP: Detection of bacterial DNA in joint samples from patients with undifferentiated arthritis and reactive arthritis, using polymerase chain reaction with universal 16S ribosomal RNA primers. Arthritis Rheum 1998, 41:535-543.

19. Jaulhac B, Sibilia J, Pourel J, Kuntz JL: Borrelia burgdorferi in Lyme arthritis and undifferentiated arthritis. Rev Rhum Engl Ed. 1999, 66:20S-22S

20. Gdoura R, Keskes-Ammar L, Bouzid F, Eb F, Hammami A, Orfila J: Chlamydia trachomatis and male infertility in Tunisia. Eur J Contracept Reprod Health Care 2001, 6:102-107.

21. Znazen A, Trigui B, Zghal-Trigui Y, Gdoura R, Zouari N, Hammami $A$ : Male gonococcal urethritis in the region of Sfax (19962000). Tunis Med 2003, 81:329-333.
22. Ben Hamida A, Kechrid A, Saadallah N, Chihi B, Kamoun R, Gueddana N: Incidence and management of male urethritis in the district of Tunis. Rev Epidemiol Sante Publique. 1999, 47:397-402.

23. Rhimi F, Ben Salah F, Trigui B, Ben Marzouk R, Abbes S, Trigui $Y$, Hammami A: Epidemiological and bacteriological aspects of shigellosis in Sfax, Tunisia (1994-1995). Med Mal Infect 2002, 32:177-183.

24. Moalla $\mathrm{H}$, Fendri $\mathrm{C}$ : Etiology of acute diarrhea in children. Tunis Med 1994, 72:25-28.

25. Dougados $M$, Linden $S$ van der, Juhlin R, Huitfeldt $B$, Amor B, Calin A, Cats A, Dijkmans B, Olivieri I, Pasero G, Veys E, Zeidler H: The European Spondylarthropathy Study Group preliminary criteria for the classification of spondylarthropathy. Arthritis Rheum 1991, 34:1218-1227.

26. Amor B: Reactive arthritis. Nosological situation, incidence and diagnostic criteria. Rev Med Interne 1986, 7:491-498.

27. Parker $\mathrm{RH}$, Pearson $\mathrm{CM}$ : A simplified synovial biopsy needle. Arthritis Rheum 1963, 6:172-176.

28. Zheng D, Alm EW, Stahl DA, Raskin L: Characterization of universal small-subunit rRNA hybridization probes for quantitative molecular microbial ecology studies. Appl Environ Microbiol 1996, 62:4504-4513.

29. Hicks RE, Amann RI, Stahl DA: Dual staining of natural bacterioplankton with 4', 6-diamidino-2-phenylindole and fluorescent oligonucleotide probes targeting kingdom-level 16S rRNA sequences. Appl Environ Microbiol 1992, 58:2158-2168.

30. Tebbe CC, Vahjen W: Interference of humic acids and DNA extracted directly from soil in detection and transformation of recombinant DNA from bacteria and a yeast. Appl Environ Microbiol 1993, 59:2657-2665.

31. Jeffries D, Farquharson C: Effects of choice of reverse-transcriptase enzyme and use of T4 gene 32 protein on banding patterns in agarose gel differential display. Anal Biochem. 2002, 308:192-194.

32. Monjardino J, James AW: Denaturation of polyoma DNA by phage T4 gene 32 protein. Nature 1975, 15:249-252.

33. Kwok S, Higuchi R: Avoiding false positives with PCR. Nature 1989, 339:237-238.

34. The ribosomal database project II software [http:// rdp8.cme.msu.edu]

35. Hannu T, Mattila L, Siitonen A, Leirisalo-Repo M: Reactive arthritis attributable to Shigella infection: a clinical and epidemiological nationwide study. Ann Rheum Dis 2005, 64:594-598.

36. Chen M, Delpech V, O'Sullivan B, Donovan B: Shigella sonnei : another cause of sexually acquired reactive arthritis. Int J STD AIDS 2002, 13:135-136.

37. Sibilia J, Limbach FX: Reactive arthritis or chronic infectious arthritis. Ann Rheum Dis 2002, 61:580-587.

38. Schaeverbeke T, Lequen L, de Barbeyrac B, Labbe L, Bebear CM, Morrier Y, Bannwarth B, Bebear C, Dehais J: Propionibacterium acnes isolated from synovial tissue and fluid in a patient with oligoarthritis associated with acne and pustulosis. Arthritis Rheum 1998, 41:1889-1893.

39. Heijden IM van der, Wilbrink B, Tchetverikov I, Schrijver IA Schouls LM, Hazenberg MP, Breedveld FC, Tak PP: Presence of bacterial DNA and bacterial peptidoglycans in joints of patients with rheumatoid arthritis and other arthritides. Arthritis Rheum 2000, 43:593-598.

40. Rand $\mathrm{KH}$, Houck $\mathrm{H}$ : Taq polymerase contains bacterial DNA of unknown origin. Mol Cell Probes 1990, 4:445-450.

41. Melief MJ, Hoijer MA, Van Paassen HC, Hazenberg MP: Presence of bacterial flora-derived antigen in synovial tissue macrophages and dendritic cells. $\mathrm{Br} J$ Rheumatol 1995 34:1112-1116.

42. Fredricks DN, Relman DA: Sequence-based identification of microbial pathogens: a reconsideration of Koch's postulates. Clin Microbiol Rev. 1996, 9:18-33.

43. Cuchacovich R, Japa S, Huang WQ, Calvo A, Vega L, Vargas RB Singh R, Flores D, Castro I, Espinoza LR: Detection of bacterial DNA in Latin American patients with reactive arthritis by polymerase chain reaction and sequencing analysis. I Rheumatol 2002, 29:1426-1429.

44. Berg RD: The indigenous gastrointestinal microflora. Trends Microbiol 1996, 4:430-435.

45. Bjarnason I: Intestinal permeability. Gut 1994:S18-S22. 
46. Kingsley G: Microbial DNA in the synovium: a role in aetiology or a mere bystander? Lancet 1997, 349:1038-1039.

47. Kool J, De Visser H, Gerrits-Boeye MY, Klasen IS, Melief MJ, Van Helden-Meeuwsen CG, Van Lieshout LM, Ruseler-Van Embden JG, Van den Berg WB, Bahr GM, Hazenberg MP: Detection of intestinal flora-derived bacterial antigen complexes in splenic macrophages of rats. J Histochem Cytochem 1994, 42:1435-1441.

48. Hoijer MA, Melief MJ, van Helden-Meeuwsen CG, Eulderink F, Hazenberg MP: Detection of muramic acid in a carbohydrate fraction of human spleen. Infect Immun 1995, 63:1652-1657.

49. Deng GM, Nilsson IM, Verdrengh M, Collins LV, Tarkowski A: Intra-articularly localized bacterial DNA containing CpG motifs induces arthritis. Nat Med 1999, 5:702-705.

50. Deng GM, Tarkowski A: The features of arthritis induced by CpG motifs in bacterial DNA. Arthritis Rheum 2000, 43:356-364.

51. Yi AK, Tuetken R, Redford T, Waldschmidt M, Kirsch J, Krieg AM: CpG motifs in bacterial DNA activate leukocytes through the $\mathrm{pH}$-dependent generation of reactive oxygen species. J Immunol 1998, 160:4755-4761. 